\title{
PENGARUH KONSENTRASI GELLING AGENT CARBOMER 934 DAN HPMC PADA FORMULASI GEL LENDIR BEKICOT (Achatina fulica) TERHADAP KECEPATAN PENYEMBUHAN LUKA BAKAR PADA PUNGGUNG KELINCI
}

\section{THE INFLUENCE OF CARBOMER 934 AND HPMC CONCENTRATION AS GELLING AGENT IN GEL FORMULATION OF MUCUS SNAIL (Achatina fulica) ON HEALING OF BURNS ON RABBIT BACK}

\author{
Tanti Azizah Sudjono*, Mimin Honniasih dan Yunita Ratna Pratimasari \\ Fakultas Farmasi, Universitas Muhammadiyah Surakarta \\ tantiums@yahoo.com
}

\begin{abstract}
ABSTRAK
Lendir bekicot mengandung glycosaminoglycan yang dapat menyembuhkan luka bakar. Sediaan ini dapat dibuat dalam bentuk gel. Perbedaan viskositas gel dapat dipengaruhi oleh gelling agent. Penelitian ini bertujuan untuk mengetahui pengaruh konsentrasi carbomer 934 dan HPMC pada formulasi gel lendir bekicot terhadap viskositas dan kecepatan penyembuhan luka bakar. Penelitian ini menggunakan rancangan penelitian sama subyek menggunakan 12 ekor kelinci jantan New Zealand yang dicukur bulu punggungnya dan dibagi menjadi 6 area perlakuan, yaitu menggunakan kontrol positif (Bioplasenton), kontrol negatif (lendir bekicot), kontrol basis dan 3 formula gel lendir bekicot dengan basis carbomer 934 konsentrasi 3, 5 dan 7\% dan untuk basis HPMC dengan variasi konsentrasi 6, 8 dan 10\%. Tiap area perlakuan diinduksi luka bakar dengan penginduksi panas berdaya $40 \mathrm{~W}, 220 \mathrm{~V}$ dan suhu $80^{\circ} \mathrm{C}$, jarak antar luka $5 \mathrm{~cm}$ dan diameter luka 2 $\mathrm{cm}$. Waktu penyembuhan luka bakar dihitung setelah semua luka tertutup oleh jaringan baru. Data diuji statistik Anava satu jalan, dilanjutkan uji LSD dengan taraf kepercayaan 95\%. Semakin tinggi konsentrasi basis, maka viskositas semakin tinggi serta waktu penyembuhannya semakin lama. Sediaan gel lendir bekicot dengan basis carbomer 934 konsentrasi 3\% lebih efektif menyembuhkan luka bakar dibanding konsentrasi $5 \%$ dan $7 \%$, yang ditunjukkan dengan waktu penyembuhan luka bakar yaitu 12,50 \pm 0,54 hari. Sedangkan gel lendir bekicot dengan basis HPMC 6\% lebih efektif dalam menyembuhan luka bakar yaitu 12,67 $\pm 0,33$ hari.
\end{abstract}

Kata kunci : Achatina fulica, Carbomer 934, HPMC, luka bakar

\section{ABSTRACT}

Snail mucus contain glycosaminoglycan could heal burns. It can be made in the gel formulation. The difference of the viscosity of gel could be influenced by gelling agent. This study was aimed to determine the effect of the difference carbomer 934 and HPMC concentration on snail mucus gel formulation viscosity and it's healing effect. This study used the same subjects using 12 male New Zealand rabbits that were shaved on the back and were divided into 6 areas of treatment, using a positive control (Bioplasenton), negative control (snail mucus) and control bases and 3 snail mucus gel formulation using carbomer 934 of 3, 5 and $7 \%$ and HPMC with various concentrations of 6, 8 and $10 \%$. Each treatment area was induced using a burns hot metal with power 40 watt, 220 volt and temperatur $80^{\circ} \mathrm{C}$, the distance of each wound $5 \mathrm{~cm}$ and $2 \mathrm{~cm}$ diameter wound. Duration healing of burns was calculated after an injury covered by the new tissues. The results were tested using one way Anova statistical, followed by LSD test with a level of 95\%. This experiment conclude that higher concentration of gelling agent cause higher viscosity and longer healing effect. Snail mucus gel preparations with Carbomer 934 concentration 3\% was more effective to heal burns than two others. it was showed that the duration healing time of burns around 12,5 $\pm 0,54$ days, while the using of gelling agent HPMC (6\%) was more effective healing of burns for $12,67 \pm 0,33$ days.

Keywords : Achatina fulica, Carbomer 934, HPMC, wound healing

\section{PENDAHULUAN}

Luka bakar merupakan trauma yang bisa diakibatkan oleh panas, arus listrik, bahan kimia dan petir yang mengenai kulit, mukosa atau jaringan yang lebih dalam (Anonim, 2001). Kulit dengan luka bakar akan mengalami kerusakan pada epidermis, dermis maupun jaringan subkutan. Derajat keparahan tergantung faktor penyebab dan lamanya kulit kontak dengan sumber panas. Luka bakar yang dalam dapat menyebabkan kerusakan atau kematian pada sel. Pada pasien dengan luka bakar luas

6 PHARMACON, Vol. 13, No. 1, Juni 2012, Sudjono,TA. et al. (6-11) 
(mayor) tubuh tidak mampu lagi untuk mengkompensasi sehingga dapat menyebabkan berbagai komplikasi yang memerlukan penanganan khusus (Effendi, 1999).

Salah satu bahan obat dari alam yang berkhasiat untuk menyembuhkan luka bakar adalah bekicot. Lendir bekicot dimanfaatkan nenek moyang untuk mempercepat pengeringan dan penutupan luka. Vieira et.al, (2004) menunjukkan bahwa lendir bekicot mengandung acharan sulfat yaitu glycosaminoglycan yang pada fase proliferasi akan membentuk komplek yang berperan penting pada penyembuhan luka (Im and Kim, 2009). Syahirah, dkk (2008) membuktikan bahwa gel lendir bekicot dengan konsentrasi $3 \%, 5 \%, 7 \%$ dan $9 \%$ dengan chitosan sebagai gelling agent mempunyai efek penyembuhan terhadap luka bakar. Gel lendir bekicot konsentrasi 9\% mempunyai kemampuan menyembuhkan luka bakar dengan waktu penyembuhan paling cepat, yaitu 14 hari

Lendir bekicot diformulasikan dalam bentuk sediaan gel yang memiliki efek mendinginkan karena mengandung banyak air sehingga diharapkan dapat membantu mempercepat proses penyembuhan luka bakar. Dalam pembuatan gel, pemilihan gelling agent sangat menentukan hasil akhir sediaan. Salah satu derivat selulosa yang efektif sebagai basis gel adalah hidroksipropil metilselulose (HPMC), yang banyak digunakan sebagai bahan tambahan baik seara oral maupun topikal (Rowe, 2006). Pemilihan basis HPMC karena gel-nya yang jernih dan tidak inkompatibel dengan bahan-bahan lain kecuali material oksidatif (Gibson, 2001). Selain HPMC, basis yang bisa digunakan adalah carbomer 934 karena mempunyai stabilitas dan kompatibilitas yang tinggi dan toksisitasnya rendah (Lu and Jun, 1998)
Atas dasar uraian di atas, maka mendorong peneliti untuk memanfaatkan lendir bekicot sebagai salah satu bahan obat yang efektif untuk penyembuhan luka bakar dan diformulasikan dalam bentuk gel dengan gelling agent carbomer 934 dan HPMC untuk mempermudah cara penggunaan dan mempercepat penyembuhan luka bakar pada kulit punggung kelinci yang diinduksi logam panas.

\section{METODE PENELITIAN \\ Alat dan Bahan}

Alat: alat untuk merangsang keluarnya lendir bekicot (electric shock), alat-alat gelas, kassa steril dan alat penginduksi panas, jangka sorong

Bahan: lendir bekicot (Achatina fulica), salep Bioplacenton ${ }^{\circledR}$, gelling agent carbomer 934, HPMC, gliserin, metil paraben, propil paraben, propilenglikol, etanol, etil klorida (anestesi lokal), sodium hydroxide $(\mathrm{NaOH})$, plester, kassa, aquadest. Hewan uji kelinci New Zealand jantan, berumur \pm 4-5 bulan dengan bobot 2,5-3,0 kg.

\section{Jalannya Penelitian:}

1. Pengambilan Lendir Bekicot (Achatina fulica)

Lendir bekicot diambil dengan cara merangsang permukaan tubuhnya menggunakan electric shock pada tegangan listrik 6 Volt selama 60 detik.

\section{Pembuatan Gel Lendir Bekicot dengan Carbomer 934 sebagai Gelling Agent}

Lendir bekicot ditampung dalam sebuah bejana dan dihomogenkan. Setelah homogen, lendir dibuat gel menggunakan resep standar.

Tabel 1- Komposisi gel lendir bekicot dengan gelling agent Carbomer 934

\begin{tabular}{lccccc}
\hline \multirow{2}{*}{ Komposisi $(\mathrm{g})$} & \multicolumn{2}{c}{ Kontrol } & \multicolumn{3}{c}{ Formula } \\
\cline { 2 - 6 } & Negatif & Positif & $\begin{array}{c}\text { I } \\
\text { (Carbomer 3\%) }\end{array}$ & $\begin{array}{c}\text { II } \\
\text { (Carbomer 5\%) }\end{array}$ & $\begin{array}{c}\text { III } \\
\text { (Carbomer 7\%) }\end{array}$ \\
\hline Bioplacenton $(\mathrm{g})$ & - & 0,5 & - & - & - \\
Lendir bekicot $(\mathrm{g})$ & 9 & - & 9 & 9 & 9 \\
Carbomer 934 $(\mathrm{g})$ & - & - & 3 & 5 & 7 \\
Metil paraben $(\mathrm{g})$ & - & - & 0,18 & 0,18 & 0,18 \\
Propilen glikol $(\mathrm{g})$ & - & - & 16,7 & 16,7 & 16,7 \\
NaOH qs pH 7 $(\mathrm{mL})$ & - & - & 10,58 & 10,74 & 11,12 \\
Aquadest ad $(\mathrm{mL})$ & - & - & 100 & 100 & 100 \\
\hline
\end{tabular}

Pembuatan gel lendir bekicot dengan basis carbomer :

Metilparaben dilarutkan ke dalam propilenglikol, kemudian carbomer 934 ditambahkan pada campuran sambil terus diaduk dengan cepat hingga terbentuk sediaan yang liat (gel), lalu disimpan pada temperatur kamar selama 24 jam. Setelah itu ditambahkan lendir bekicot dan $\mathrm{pH}$ diatur sampai 7 dengan penambahan $\mathrm{NaOH}$ $1 \%$. Aquades ditambahkan sampai volume 100 $\mathrm{ml}$, kemudian dimasukkan dalam tube. Fungsi propilen glikol adalah sebagai humektan. 
Tabel 2- Komposisi gel lendir bekicot dengan gelling agent HPMC

\begin{tabular}{lccccc}
\hline \multirow{2}{*}{ Komposisi $(\mathrm{g})$} & \multicolumn{3}{c}{ Kontrol } & \multicolumn{3}{c}{ Formulasi } \\
\cline { 2 - 6 } & Negatif & Positif & $\begin{array}{c}\text { I } \\
\text { (HPMC 6\%) }\end{array}$ & $\begin{array}{c}\text { III } \\
\text { (HPMC 8\%) }\end{array}$ & (HPMC 10\%) \\
\hline Bioplacenton & - & 0,5 & - & - & - \\
Lendir bekicot $(\mathrm{g})$ & 9 & - & 9 & 8 & 9 \\
HPMC $(\mathrm{g})$ & - & - & 6 & 0,075 & 10 \\
Metil paraben $(\mathrm{g})$ & - & - & 0,075 & 0,025 & 0,075 \\
Propil paraben $(\mathrm{g})$ & - & - & 0,025 & 10 & 0,025 \\
Gliserin $(\mathrm{mL})$ & - & - & 1 & 1 & 10 \\
Etanol $(\mathrm{mL})$ & - & - & 100 & 100 & 1 \\
Air ad $(\mathrm{mL})$ & - & - & & 100 \\
\hline
\end{tabular}

\section{Pembuatan gel lendir bekicot dengan basis HPMC:}

HPMC didispersikan pada $30 \mathrm{ml}$ air pada suhu $80-90^{\circ} \mathrm{C}$ hingga mengembang dan diaduk dengan cepat hingga liat (gel), kemudian ditambahkan air dingin 20-30 ml dan diaduk. Metil paraben dan propil paraben dilarutkan dalam $1 \mathrm{ml}$ etanol lalu ditambah $10 \mathrm{mg}$ gliserin dan lendir bekicot. Campuran yang diperoleh dimasukkan dalam HPMC liat dan diaduk sampai homogen, ditambahkan air dingin hingga didapat 100,0 gram gel, selanjutnya dikemas dalam tube. Metil paraben dan propil paraben berfungsi sebagai pengawet, gliserin sebagi humektan (penahan lembab)

\section{Pengujian Gel Lendir Bekicot}

a. Uji Organoleptis dan Stabilitas Gel Lendir Bekicot dengan Gelling Agent Carbomer 934 dan HPMC

Sediaan gel lendir bekicot diuji stabilitasnya dengan memperhatikan warna, bau, dan konsistensi selama penyimpanan. Diamati perubahannya setiap minggu selama 5 minggu penyimpanan.

b. Uji Homogenitas Gel Lendir Bekicot

Sediaan gel lendir bekicot diuji homogenitasnya dengan mengoleskannya pada sekeping kaca preparat (transparan). Dilihat ada tidaknya partikel / zat yang belum tercampur secara homogen.

c. Pengukuran pH Gel Lendir Bekicot Sediaan gel lendir bekicot diukur pH-nya menggunakan $\mathrm{pH}$ meter yang telah dikalibrasi untuk mengetahui apakah $\mathrm{pH}$ gel sesuai dengan $\mathrm{pH}$ kulit $(4-6,5)$.

d. Uji Viskositas Gel Lendir Bekicot

Alat yang digunakan untuk uji viskositas adalah viskometer VT-04E RION Co, TLD. Mangkuk diisi setengah sampel gel yang akan diuji. Rotor ditempatkan di tengahtengah mangkuk yang berisi gel, kemudian alat dihidupkan agar rotor mulai berputar. Jarum penunjuk viskositas secara otomatis akan bergerak ke kanan. Setelah stabil, kemudian dibaca pada skala yang terdapat pada viskosimeter tersebut.

\section{Pembuatan Luka Bakar}

Luka bakar dibuat dengan menginduksi kulit punggung kelinci menggunakan alat penginduksi panas berupa lempeng logam bersuhu $80^{\circ} \mathrm{C}$, selama 5 detik. Logam berdiameter $2 \mathrm{~cm}$ yang dihubungkan elemen panas berdaya $40 \mathrm{~W}$ dan tegangan 220 Volt. Jarak antar luka $\pm 5 \mathrm{~cm}$ (Suratman dkk, 1996). Sebelumnya, bulu pada punggung kelinci dicukur, lalu dianestesi dengan Etyl chlorida spray yang disemprotkan pada kulit yang akan dibuat luka bakar.

\section{Pengujian Efek Penyembuhan Luka Bakar Gel Lendir Bekicot dengan basis carbomer 934 serta basis HPMC}

Untuk pengujian efek penyembuhan luka bakar, digunakan 12 kelinci jantan yang dibagi dalam dua kelompok masing-masing 6 kelinci. Kelompok I kelinci dibuat luka bakar dalam 6 area (1,2,3,4,5 dan 6), kelompok II juga dibuat luka bakar dengan 6 area yaitu $(1,2,7,8,9$ dan 10) seperti pada gambar 1

Masing-masing luka bakar diberi perlakuan sebagai berikut:

Bagian 1 : Diberi salep Bioplacenton ${ }^{\circledR}$ sebagai kontrol positif

Bagian 2 : Diberi lendir bekicot sebagai kontrol negatif

Bagian 3 : Diberi carbomer 934 sebagai kontrol basis

Bagian 4 : Diberi gel lendir bekicot dengan gelling agent carbomer 934 [3\%]

Bagian 5 : Diberi gel lendir bekicot dengan gelling agent carbomer 934 [5\%]

Bagian 6 : Diberi gel lendir bekicot dengan gelling agent carbomer 934 [7\%]

Bagian $7 \quad$ : Diberi HPMC sebagai kontrol basis

Bagian 8 : Diberi gel lendir bekicot dengan gelling agent HPMC [6\%]

Bagian $9 \quad$ : Diberi gel lendir bekicot dengan gelling agent HPMC [8\%]

Bagian 10 : Diberi gel lendir bekicot dengan gelling agent HPMC [10\%]

Luka bakar yang telah dibuat, diolesi dengan sediaan uji sebanyak 0,3 gram sekali sehari, kemudian ditutup dengan kain kassa steril dan plester untuk mengurangi kemungkinan kontaminasi bakteri. 


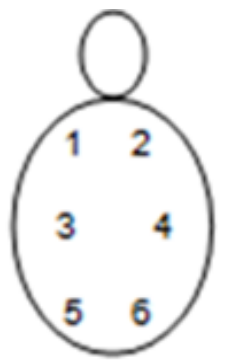

Kelinci $(n=6)$

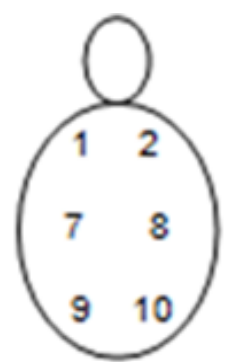

Kelinci $(n=6)$
Gambar 1- Model Lokasi Pembuatan Luka Bakar di Bagian Punggung Kelinci

\section{Analisis Data}

Parameter yang digunakan adalah persentase penyembuhan luka bakar pada hari ke- $x$. Perhitungan persentase penyembuhan luka dilakukan dengan rumus sebagai berikut :

$$
P x=\frac{d x_{1}^{2}-d x_{n}^{2}}{d x_{1}^{2}} \times 100 \%
$$

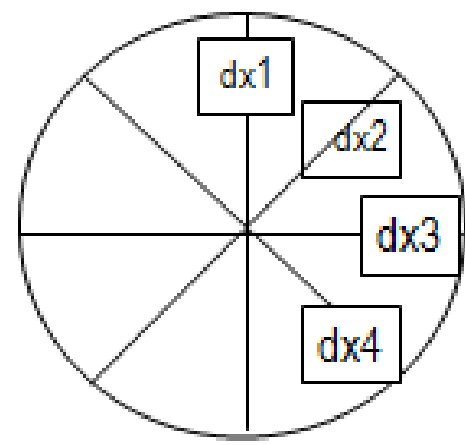

Gambar 2- Cara Mengukur Diameter Luka Keterangan :

$\mathrm{Px}=$ persentase penyembuhan luka bakar pada hari ke-x $\mathrm{dx}_{1}=$ diameter luka bakar hari pertama

$\mathrm{dx}_{\mathrm{n}}=$ diameter luka bakar hari ke-n (Suratman dkk, 1996)
Data waktu penyembuhan luka bakar dianalisis secara statistik dengan uji parameterik analisis varian (ANAVA) satu jalan, dilanjutkan uji LSD (Least Significant Different) dengan taraf kepercayaan $95 \%$.

\section{HASIL DAN PEMBAHASAN}

\section{A. Identifikasi Lendir Bekicot}

1. Hasil Pengambilan Lendir Bekicot

Lendir bekicot dihomogenkan dan diuji $\mathrm{pH}$ serta viskositasnya. Nilai $\mathrm{pH}$ yang didapat sebesar 8,53 dan viskositasnya sebesar 125 dPA-s.

2. Organoleptis Lendir Bekicot

Konsistensi kental; warna kuning jernih dan tidak berbau

B. Hasil Pembuatan dan Pengujian Gel Lendir Bekicot dengan Gelling Agent Carbomer 934 dan HPMC

1. Homogenitas Gel Lendir Bekicot

Gel lendir bekicot dengan basis carbomer 934 dan HPMC diuji tingkat homogenitasnya untuk memastikan semua bahan tercampur dengan baik. Hasil yang diperoleh semua sediaan homogen (Tabel 3).

2. Stabilitas Gel Lendir Bekicot

Gel lendir bekicot dengan basis carbomer 934 dan HPMC diuji stabilitasnya dengan memperhatikan warna, bau, dan konsistensi selama penyimpanan 5 minggu. Berdasar hasil pengamatan tiap minggu selama 5 minggu penyimpanan, gel lendir bekicot tidak mengalami perubahan warna, bau (organoleptis) dan konsistensi (dicek menggunakan viscosimeter). Sehingga dapat disimpulkan bahwa gel lendir bekicot stabil dalam 5 minggu penyimpanan (Tabel 3)

Tabel 3- Pengujian homogenitas, organoleptis, $\mathrm{pH}$ dan viskositas gel lendir bekicot dengan basis carbomer 934 dan basis HPMC

\begin{tabular}{|c|c|c|c|c|}
\hline Perlakuan & Homogenitas & Warna dan bau & $\mathrm{pH}$ & $\begin{array}{c}\text { Viskositas } \\
\text { (dPAS) }\end{array}$ \\
\hline Kontrol negatif ( lendir bekicot ) & Homogen & Kuning jernih tidak berbau & 8,53 & 125 \\
\hline Basis carbomer 934 & Homogen & Putih kekuningan, bau khas & & \\
\hline Lendir bekicot + carbomer $7 \%$ & Homogen & Putih kekuningan, bau khas & 7,00 & 120 \\
\hline Basis HPMC & Homogen & Kuning jernih, tidak berbau Kuning & & \\
\hline Lendir bekicot + HPMC 6\% & Homogen & jernih, tidak berbau & 7,58 & 60 \\
\hline Lendir bekicot + HPMC 8\% & Homogen & Kuning jernih, tidak berbau & 7,71 & 75 \\
\hline Lendir bekicot + HPMC 10\% & Homogen & Kuning jernih, tidak berbau & 7,93 & 85 \\
\hline
\end{tabular}




\section{Efek Penyembuhan Luka Bakar Gel Lendir Bekicot}

Tabel 4- Waktu rata-rata penyembuhan luka bakar oleh gel lendir bekicot dengan basis carbomer 934 dan basis HPMC ( $\mathrm{n}=6$ ekor)

\begin{tabular}{|c|c|}
\hline Perlakuan & Lama penyembuhan luka bakar (hari) \\
\hline Kontrol negatif (lendir bekicot) & $16,53 \pm 0,51$ \\
\hline Basis Carbomer 934 & $18,50 \pm 0,54^{*}$ \\
\hline Lendir bekicot + Carbomer $5 \%$ & $14,50 \pm 0,54^{*}\left({ }^{* *}\right)$ \\
\hline Lendir bekicot + Carbomer $7 \%$ & $16,50 \pm 0,54 \quad\left(^{* *}\right)$ \\
\hline Basis HPMC & $19,50 \pm 0,55^{\star}$ \\
\hline Lendir bekicot + HPMC 10\% & $15,83 \pm 0,31 \quad\left({ }^{\star *}\right)$ \\
\hline
\end{tabular}

Hasil uji efek penyembuhan luka bakar menunjukkan adanya perbedaan waktu penyembuhan luka, semakin tinggi konsentrasi gelling agent yang digunakan maka semakin lama waktu penyembuhan (Tabel 4). Hal ini dikarenakan semakin tinggi konsentrasi gelling agent, maka semakin tinggi pula viskositasnya/kekentalannya (Tabel 3), sehingga zat aktif yang terkandung dalam sediaan akan semakin sulit untuk dilepaskan.

Hasil uji LSD diketahui bahwa kontrol positif, gel lendir bekicot dengan basis carbomer konsentrasi 3 dan $5 \%$ serta gel lendir bekicot dengan basis HPMC konsentrasi 6 dan $8 \%$ berbeda bermakna dengan kontrol negatif $(p<0,05)$. Hal ini menunjukkan kontrol positif, gel lendir bekicot dengan basis carbomer 3 dan $5 \%$ serta gel lendir bekicot dengan basis HPMC konsentrasi 6 dan 8\% mampu mempercepat penyembuhan luka bakar. Sedangkan gel lendir bekicot berbasis carbomer $3 \%$ dan berbasis HPMC $6 \%$ berbeda tidak bermakna terhadap kontrol positif bioplacenton. Hal ini menunjukkan efek penyembuhan luka bakar antara gel lendir bekicot berbasis carbomer 3\% dan HPMC 6\% memiliki efek setara dengan kontrol positif bioplacenton. Berdasarkan ratarata waktu penyembuhan, tampak bahwa kontrol positif dan gel lendir bekicot carbomer $3 \%$ dan HPMC 6\% memiliki waktu penyembuhan luka bakar yang lebih cepat dibandingkan formula lain.
Waktu penyembuhan luka bakar gel lendir bekicot dengan gelling agent carbomer konsentrasi $3 \%$ lebih cepat dibanding konsentrasi $5 \%$ dan $7 \%$, dan gel lendir bekicot berbasis HPMC $6 \%$ lebih cepat menyembuhkan luka bakar dibanding yang konsentrasi 8 dan $10 \%$. Semakin kecil konsentrasi gelling agent maka viskositas gel lendir bekicot semakin kecil sehingga kecepatan difusi obatnya menjadi lebih besar. Semakin besar viskositas suatu zat maka difusi obatnya akan semakin menurun karena pelepasan obat dari basis berkurang (Sinko, 2006)

\section{KESIMPULAN}

1. Semakin tinggi konsentrasi gelling agent carbomer 934 dan juga HPMC, maka semakin tinggi pula viskositasnya dan semakin lama waktu penyembuhan luka bakar.

2. Sediaan gel lendir bekicot (Achatina fulica) dengan gelling agent carbomer 934 konsentrasi $3 \%$ mempunyai efek penyembuhan luka bakar lebih cepat dibanding konsentrasi 5 dan $7 \%$ yaitu dengan lama penyembuhan $12,5 \pm 0,54$ hari, sedangkan gel lendir bekicot dengan gelling agent HPMC konsentrasi 6\% menunjukkan efek penyembuhan lebih cepat dibanding konsentrasi 8 dan 10\% yaitu dengan waktu penyembuhan $12,67+0,33$ hari

\section{DAFTAR PUSTAKA}

Anonim, 2001, Pendidikan Keperawatan Berkelanjutan (PKB V) Tema : Asuhan Keperawatan Luka Bakar Secara Paripurna, Instalasi Rawat Inap Bedah RSUD Dr. Soetomo Surabaya.

Effendi, C., 1999, Perawatan Pasien Luka Bakar, Penerbit Buku Kedokteran EGC Press, Jakarta, $1-2,10$

Gibson, M., 2001, Pharmaceutical Preformulation and Formulation, CRC Press, United States of America.

Im, A-R., and Kim, Y.S., 2009, Role of Glycosaminoglycans in Wound Healing, Natural Products Research Institute, College of Pharmacy, Seoul National University, Korea, 1 (2) : 106-114. 
Lu, G., and Jun, H.W, 1998, Diffusion of Methotrexate in Carbopol and Poloxamer Gels, International Journal of Pharmaceutic

Sinko, P.J., 2006, Martin's Physical Pharmacy and Pharmaceutical Sciences : Physical Chemical and Biopharmaceutical Principles in the Pharmaceutical Sciences, $5^{\text {th }}$ ed, Published Philadelphia : Lippincott Williams \& Wilkins

Rowe, R.C., Jheskey, P.J., and Owen, S.C., 2006, Handbook of Pharmaceutical Excipients, Pharmaceutical Press, USA

Suratman, Sumiwi, S.A., dan Gozali, D., 1996, Pengaruh Ekstrak Antanan dalam Bentuk Salep, Krim, Dan Jelly Terhadap Penyembuhan Luka Bakar, Cermin Dunia Kedokteran, 31-36

Syahirah F., Naila M., Anggraini T.A., 2008, Formulasi Salep Lendir Bekicot (Achatina fulica) terhadap Penyembuhan Luka Bakar pada Kelinci Jantan New Zealand, Laporan PKM, Fakultas Farmasi, Universitas Muhammadiyah Surakarta, Surakarta.

Vieira, T.C.R.G., Costa-Filho, A., Salgado, N.C., Allode, S., Valente, A.P., Nasciutti, L.E., and Silva, L.C.F., 2004, Acharan sulfate, the new glycosaminoglycan from Achatina fulica Bowdich 1822, European Journal of Biochemistry, $271: 845-854$ 